\title{
Persistent effects of disturbance on larval patterns in the plankton after an eruption on the East Pacific Rise
}

\author{
S. W. Mills ${ }^{1, *}$, L. S. Mullineaux ${ }^{1}$, S. E. Beaulieu ${ }^{1}$, D. K. Adams ${ }^{1,2}$ \\ ${ }^{1}$ Biology Department, Woods Hole Oceanographic Institution, Woods Hole, Massachusetts \\ 02543, USA \\ ${ }^{2}$ Present address: Institute of Marine and Coastal Sciences, Rutgers University, 71 Dudley Road, \\ New Brunswick, New Jersey 80901, USA \\ *Email: smills@whoi.edu \\ Running head: Mills et al.: Post-eruption changes in vent larvae
}

\begin{abstract}
To predict how benthic communities will respond to disturbance, it is necessary to understand how disturbance affects the planktonic larval supply available to recolonize the area. Deep-sea hydrothermal vent fauna along the East Pacific Rise (EPR) experience frequent local extinctions due to tectonic and magmatic events, but the effects on regional larval abundance and diversity are unknown. We had been monitoring larvae at 9 50' $\mathrm{N}$ on the EPR prior to the 2006 eruption and were able to resume collections shortly afterward. We found that many species that were common before the eruption became significantly less so afterward, whereas a few other species experienced a transient spike in abundance. Surprisingly, overall species richness in the plankton was high 9 mo after the eruption, but then decreased sharply after $1 \mathrm{yr}$ and had not returned to pre-eruption levels after 2 yr. These results suggest that recovery from disturbance may continue to be affected by limited larval supply even several years after a disturbance event. This delay in recovery means that larvae of pioneer species may dominate potential colonists, even after benthic habitats have transitioned to conditions that favor later-successional species. Moreover, the combined effects of natural and anthropogenic disturbance (e.g. mining) would be likely to cause more profound and long-lasting changes than either event alone. Our results indicate that we do not have sufficient data to predict the timing of recovery after disturbance in the deep sea, even in a well-studied vent system.
\end{abstract}


KEY WORDS: Recolonization · Deep sea · Hydrothermal vents · Disturbance ecology · Ecological succession · Larval supply $\cdot$ Larval dispersal

\section{INTRODUCTION}

Hydrothermal vents at fast-spreading centers such as the East Pacific Rise (EPR) are subject to frequent (annual to decadal) disturbance (Fornari et al. 2012). Sites may be paved over with lava during volcanic eruptions and even minor earthquakes may divert the flow of hydrothermal fluids, causing established communities to perish while creating new habitat elsewhere. Because most of the vent-endemic fauna have limited mobility as adults, colonization of disturbed sites must be primarily by planktonic larvae (Lutz et al. 1984). The abundant food source supplied by chemosynthetic bacteria and archaea allows for high reproductive rates and many species have quasi-continuous reproduction (Tyler \& Young 1999), so that in the event of an eruption some larvae are likely to be available to recolonize the site. Yet, surprisingly little is known about the process by which this occurs.

The EPR at $9^{\circ} 50^{\prime} \mathrm{N}$ has been studied through an entire eruption cycle (1991 to 2006) and faunal recoveries from 2 eruptions have been observed. Because the site was not sampled until shortly before the 1991 eruption, little information was available on the pre-1991 fauna and the recovery was followed mainly by observing megafauna (Shank et al. 1998), supplemented by non-quantitative macrofaunal collections. During the 15 yr between the 2 eruptions, the area was studied intensively by numerous researchers, who produced quantitative information on macrofaunal species composition and abundance (e.g. Micheli et al. 2002, Mullineaux et al. 2003, Van Dover 2003, Dreyer et al. 2005, Govenar et al. 2005) and measured the diversity, abundance and distribution of vent larvae through time using plankton pumps and sediment traps (Mullineaux et al. 2005, Beaulieu et al. 2009). These studies support the idea of vents as a dynamic environment: physically through initiation and cessation of venting (e.g. the emergence of high temperature vents at Tica and termination of venting at Tubeworm Pillar; Von Damm et al. 2004) and through changes in vent fluid temperature, $\mathrm{pH}$ and chemical composition on short and long time scales (Le Bris et al. 2006a,b, Lutz et al. 2008, Moore et al. 2009), and biologically through succession and other processes (Micheli et al. 2002, Mullineaux et al. 2003). 
The megafauna appear to have followed the same general patterns of arrival during the recoveries from the 1991 and 2005/2006 eruptions; first the Jericho worm Tevnia jerichonana colonized numerous small venting sites with the giant tubeworm Riftia pachyptila gradually replacing it during the second and third years after the disturbance. Bathymodiolus thermophilus mussels appeared as isolated individuals during this same time frame, but they remained infrequent even 4 yr post-eruption, in 1995 and 2010 (Shank et al. 1998, Mullineaux et al. 2012). However, even with very limited information about the differences in macrofauna, it was apparent that recovery from the 2005/2006 eruption event differed from its predecessor, with the widespread appearance of a newly arrived gastropod species Ctenopelta porifera, which had never been collected from this site before (Mullineaux et al. 2010), and the dominance of another gastropod, Lepetodrilus tevnianus, which had not been prominent after the previous event. It is unknown whether the absence of $C$. porifera after the 1991 eruption was due to differences in the post-eruption environment or lack of larvae in the plankton at the critical stage in the recovery.

Larval dispersal is a critical part of dynamics in a metapopulation with frequent natural disturbance (Van Dover \& Lutz 2004, Neubert et al. 2006, Metaxas 2011), determining whether and how fast disturbed communities recover. The rate and character of recolonization influence the distribution of species and both local and regional diversity. It is, however, uncertain whether the adaptations that allow vent communities to recover after eruptions would be equally effective after a different type of disturbance, such as open-cut mining. Although mining on remote sections of mid-ocean ridges may be unlikely, mining is currently being proposed for moreaccessible arc and back-arc settings in the western Pacific (Hoagland et al. 2010). The general consensus appears to be that because vent populations are adapted to frequent disturbance, they are likely to recover quickly from a mining operation or other anthropogenic disturbance, provided that nearby areas with similar fauna are set aside as reserves to act as sources of larvae to recolonize the site. Yet, decisions on appropriate methods of restoration are being made without data on larval supply (Van Dover et al. 2011) — the most critical factor in recovery after disturbance.

We have been sampling larvae at $9^{\circ}$ 50' $\mathrm{N}$ intermittently since 1998 and have quantitative larval samples from shortly before the eruption and soon afterward. In this study, we used these samples to examine how larval abundance and species composition changed following the disturbance and how larval variation corresponded to changes observed in the benthic 
populations. With this information, we evaluated how information on larval abundance and species composition can help inform predictions of community composition and succession after future eruptions or different types of disturbance.

\section{MATERIALS AND METHODS}

Our study was conducted at the Ridge 2000 Integrated Studies Site (ISS) near $9^{\circ} 50^{\prime} \mathrm{N}$ on the EPR . The study locations were all within the area impacted by the 2005/2006 eruption (Tolstoy et al. 2006), where the bottom was paved over with lava and existing populations were destroyed (Fig. 1). We used January 22, 2006 as the eruption date, although it is possible that some lava may have been extruded in late 2005. The nearest known surviving intact populations were at the V vent, roughly $6 \mathrm{~km}$ to the south (Soule et al. 2007). Samples were collected on 4 cruises, one pre-eruption in November 2004 at the East Wall vent ( $\mathrm{n}=5$ samples; Beaulieu et al. 2009) and 3 post-eruption in November $2006(n=3)$, December $2006(n=3)$ and November $2007(\mathrm{n}=4)$ as part of the LADDER cruises L1, L2 and L3, respectively (Thurnherr et al. 2011). These particular post-eruption samples were selected because they were all collected nearbottom, on-axis and within $1 \mathrm{~km}$ of the location where the pre-eruption samples were taken (Riftia Field, Tica and Ty/Io vents in 2006; Tica vent in 2007; note that the East Wall site was no longer active after the eruption). Although we have no evidence that reproduction at these vents is seasonal, all samples were taken at roughly the same time of year. Additional larval data from 1999 and 2000 samples at vents near 9 50' N (Mullineaux et al. 2005) were used in analyses of larval abundance but not in analyses of species composition because our taxonomic resolution had increased by 2004.

Samples were collected by large volume pumps (McLane Large Volume Water Transfer System WTS-LV50, McLane Research Laboratories) deployed on free-standing moorings at $4 \mathrm{~m}$ above bottom. Moorings were deployed anchor first, and positioned within a surveyed long baseline navigation net on the sea floor using an EdgeTech Model 8242XS relay transponder. On the post-eruption cruises, moorings were repositioned, if necessary (before initiation of pumping), by the DSV ‘Alvin’. Each pump was programmed to start at a specific time, and filtered at $30 \mathrm{l} \mathrm{min}^{-1}$ for $24 \mathrm{~h}$. All pumps collected full samples ( 41500 l) except one that stopped prematurely (East Wall sample b: 2004: 29840 l). Larvae were collected on a $63 \mu \mathrm{m}$ screen inside the high-volume filter holder, where they remained for a short period $(<2 \mathrm{~h})$ until 
the mooring was released acoustically and recovered. Since the filter holders are well insulated, the samples stayed cold, typically $<5^{\circ} \mathrm{C}$, during the recovery and many of the larvae were alive when they reached the surface. On recovery of the moorings, the samples were transferred to chilled filtered seawater for a short examination and then preserved in 95\% ethanol.

Samples were sorted in the laboratory and all larvae were classified to the lowest possible taxonomic group (genus or species for most molluscs and arthropods, family or genus for polychaetes, as in Mullineaux et al. 2005, Beaulieu et al. 2009 and Mills et al. 2009). For most of these larvae, it was not possible to determine developmental stage, so those observations were not included in analyses. Every effort was made to assign individuals to species-level morphotypes, but this was not possible in all cases, especially that of the limpet genus Lepetodrilus, which has 5 described local species and probably other cryptic species (Johnson et al. 2008). Ideally, species-level identifications would be used for comparisons of richness, but in the deep sea where many taxa have not been identified to species level, richness analyses that mix species and higher taxa have proven informative for ecological investigations (e.g. Levin et al. 2009). For all tests except rarefaction, species abundances were normalized to a sample size of 400001 prior to analysis.

We conducted a Bray-Curtis cluster analysis to look at relationships between the samples both individually and pooled by sampling date (BioDiversity Pro, Scottish Museum of Marine Science). We selected the single-link approach for simplicity; the other options produced virtually identical clusters. Patterns of species co-occurrence were evaluated using nonmetric multi-dimensional scaling (nMDS; Systat 11), focusing on 12 gastropod species, including the most common pre-eruption species or morphotypes, plus Ctenopelta porifera, which appeared in the benthos for the first time after the eruption (Mullineaux et al. 2010). This analysis revealed 2 discrete groups; 4 species were selected from each group and examined by multivariate analysis of variance (MANOVA; Systat 11) to evaluate changes in abundance over time. We limited the species to 4 (those with highest abundance that were also found in the benthos) to ensure that the number of species did not exceed the number of replicates for any sample date. Logarithmic transformations, $\ln (x+1)$, were performed when necessary to approach homogeneity of variance. Post-hoc Tukey tests were conducted to identify significant pairwise differences between sample dates. Finally, we evaluated species richness and diversity for all the samples using rarefaction curves (BioDiversity Pro), Shannon's diversity $\left(H^{\prime}\right)$ and Pielou's evenness $\left(J^{\prime}\right)$ 
measures (Pielou 1969). Abundances of all vent larvae combined, and of gastropod and polychaete groups separately, were compared between cruises by ANOVA and Tukey tests (Systat 11), and to earlier sampling expeditions in 1999 and 2000 (Mullineaux et al. 2005), to evaluate temporal variation and compare it with diversity patterns. MANOVA data were logtransformed when necessary.

\section{RESULTS}

We found a total of 56 benthic species or morphotypes (Table 1) in the larval samples, most of which were of vent or probable vent origin. In the cluster analysis (Fig. 2), the 2004 samples clustered together, indicating similar species composition, and were separate from the post-eruption samples. The 2007 samples formed a discrete group, but the 2006 samples fell into 2 clusters, with the southern (Ty/Io) collections in one, the northern (Riftia Field) collections in the other, and the Tica collections split between the two. The cluster containing the 2006 Ty/Io samples and the December Tica sample was least similar to all other groups. An examination of species abundance in the samples showed low total numbers of larvae (mean abundance roughly $25 \%$ of the other 2006 cluster) and relatively low abundance of species that were dominant in other post-eruption samples (full data set is available in the Ridge 2000 data portal of the Marine Geosciences Data System: www.marine-geo.org/portals/ridge2000). Thus, the cause of this difference between the two 2006 clusters appears to be associated with sample size, rather than geographical location.

The nMDS analysis divided gastropods into 2 groups: one with species that were common in pre-eruption samples of benthos and plankton (Mullineaux et al. 2003, 2005, Beaulieu et al. 2009), and a second including Gorgoleptis emarginatus and Ctenopelta porifera, species that were common in post-eruption samples (Mullineaux et al. 2010) (Fig. 3).

MANOVA revealed significant differences between cruises in all 4 species selected from the pre-eruption group, and 2 of the 4 species in the post-eruption group (Table 2, Fig. 4). As expected, species in the pre-eruption group were most common in the 2004 samples. Cyathermia naticoides abundance dropped sharply between 2004 and the first post-eruption cruise (November 2006) and remained low throughout the post-eruption sampling period. Abundances of the other 3 species fell more slowly, with Peltospira spp. and Rhynchopelta concentrica not 
significantly different from pre-eruption levels until the second LADDER cruise in December 2006 and Neomphalus fretterae not until the 2007 cruise.

Ctenopelta and Gorgoleptis emarginatus, by contrast, both increased significantly in abundance after the eruption. C.porifera abundances fell sharply after the first LADDER cruise, but remained above pre-eruption levels into 2007. G. emarginatus remained common throughout 2006, but abundances had dropped by November 2007. Sutilizona theca and Lepetodrilus spp. did not show significant differences between cruises but followed the same general pattern of lower abundances prior to the eruption, highest immediately afterward and declining gradually through 2006 and 2007. Lepetodrilus spp. potentially includes 5 different species, some (e.g. L. elevatus, $L$. pustulosus and $L$. ovalis) that were common in the benthos before the eruption and one (L. tevnianus) that was dominant afterward (Mullineaux et al. 2010). We suspect that the pre-eruption samples contained mostly L. elevatus and the post-eruption ones L. tevnianus but have not been able to confirm this with molecular genetic identifications.

Species richness in individual larval samples at 9 mo after the eruption (November 2006) was as high as in the pre-eruption (2004) samples (Fig. 5). However, there was a drop shortly afterward and subsequent curves (December 2006 and November 2007) fell below those from 2004 and November 2006. Species richness in pooled samples from each date showed the same general pattern - a decline in species richness after November 2006. None of the pooled samples contained enough individuals to represent the full diversity of species for a given date (i.e. none of the rarefaction curves approached an asymptote). The Shannon $H^{\prime}$ (diversity) and Pielou's $J$ (evenness) measures showed a similar pattern of relatively high diversity and evenness in 2004 and November $2006\left(H^{\prime}=1.13\right.$ and 1.03, and $J^{\prime}=0.66$ and 0.63, respectively) followed by lower diversity in December 2006 and November 2007 ( $H^{\prime}=0.90$ and 0.79, and $J^{\prime}=$ 0.58 and 0.49 , respectively).

The abundance of vent larvae as a group was highest in 2004 and lowest in 1999 (Fig. 6). This pattern was driven largely by high polychaete abundance in 2004. Gastropod abundances tended to be highest in 2006 (November and December), then fell to approximately 2004 levels by 2007, but these differences were not significant. One striking feature of larval abundance patterns was the high variance in post-eruption sample sets in 2006. The patterns in vent larval abundance show a modest (non-significant) decrease over time after the eruption but do not show 
the distinct drop between the November and December 2006 cruises that was evident in species richness.

\section{DISCUSSION}

\section{Larval abundance and species composition}

We had expected that both larval abundance and species richness would drop following the eruption, due to the loss of the local source populations and the limited number of species observed in the benthic communities immediately following the eruption. The disturbed area near $9^{\circ} 50^{\prime} \mathrm{N}$ has a high concentration of vents and vent communities (Fornari et al. 2012), and previous observations there showed that communities contributed substantially to local larval supply (Adams \& Mullineaux 2008). Low diversity in early successional communities is a classic pattern in disturbed habitats, both marine and terrestrial (McCook 1994, Sousa 2001), and could result in depression of local larval diversity. Instead, species richness in the plankton was high at 9 mo after the eruption. This unanticipated pattern is probably due to the arrival and establishment of pioneer species in the disturbed benthos (Mullineaux et al. 2010) in combination with a continued supply of larvae from neighboring, undisturbed communities, less than $10 \mathrm{~km}$ away. For instance, larvae of the pioneer Ctenopelta porifera, which appears to be able to exploit the conditions that were common at that time - high $\mathrm{H}_{2} \mathrm{~S}$, high temperature, extensive bacterial mats (Mullineaux et al. 2012) — were particularly abundant in our first posteruption samples, but pre-eruption species (e.g. gastropods Cyathermia naticoides, Peltospira spp. and Rhynchopelta concentrica) were also present in low numbers. The high post-eruption diversity was short-lived, with 10 species disappearing and the pioneer $C$. porifera declining greatly in abundance between the sampling periods at the end of 2006.

Changes in larval abundance in the plankton did not correspond closely to changes in species diversity. Total number of larvae declined only slightly, and not significantly, over the period between November and December 2006, when the greatest change in diversity occurred. High variation in abundance within each of those sampling intervals indicates that larval distributions were patchy at those times. Some of the variation may have been due to sampling at multiple sites, or possibly to changes in current-mediated transport from nearby source populations (as in Adams \& Mullineaux 2008). 
It is possible that spawning by surviving adults, mainly outside the lava-covered region, may have contributed to high larval diversity directly after the eruption. Nearby populations may have spawned as part of their natural routine, or in response to hydrological changes associated with the eruption that produced chemical or nutritional triggers to stimulate their gamete production. Earthquake tremors were detected far outside the lava coverage (Dziak et al. 2009), and it is also possible that physical disruption may cue spawning, as has been observed in coastal limpet species (Shanks 1998). This explanation would suggest that larval abundances may have been even higher before our earliest post-eruption plankton pump sampling, and there is some evidence that this could have been the case. In a time-series sediment trap placed on-axis in June 2006, the abundances of the most numerous gastropods, Cyathermia naticoides, Lepetodrilus spp. and Gorgoleptis emarginatus, were highest in the first samples taken in July (Mullineaux et al. 2010). While these trap samples measure larval flux to the bottom rather than absolute abundance and tend to collect fewer species than pumps (Beaulieu et al. 2009), species richness was also higher in July 2006 (9 to 15 species per 6 d sample) than it was in September 2006 (5 to 11 species per $6 \mathrm{~d}$ sample) a few months before our pump sampling started.

To some degree, there appears to have been a disconnect between larval availability and the recovery of benthic populations. Post-eruption studies of macrofauna at this site and at vents on the Juan de Fuca Ridge in the NE Pacific show that after the initial local extinctions there is a gradual recovery of species diversity in the benthos over a period of several years (Tunnicliffe 1997, Shank et al. 1998, Marcus et al. 2009, Mullineaux et al. 2012). At 9 50’ N, the early posteruption benthic macrofaunal populations consisted mostly of small patches of Tevnia jerichonana, with associated limpets and polychaetes, and large numbers of juvenile bythograeid and galatheid crabs (Fornari et al. 2012). Species richness increased gradually from November 2006 to November 2007 but had not yet reached pre-eruption levels by 2 yr after the eruption (Mullineaux et al. 2012). In contrast, larval diversity was high after the benthic populations crashed and then declined abruptly some months later, between November and December 2006. It seems unlikely that larvae produced before the eruption could remain in the plankton for that length of time; while pelagic larval duration is poorly constrained for most vent larvae, bottom currents would have carried most pre-eruption larvae away from the site in a matter of months (McGillicuddy et al. 2010). The simplest explanation is that larval production increased in 
surviving populations after the eruption, but fell back at some point to pre-eruption levels or below, except in the few species capable of exploiting the new environment.

Several details in the larval data are curious. Larval abundance, both overall and for many prominent species, was highly variable between samples in the first 2 plankton sampling periods after the eruption. Geographic effects due to sampling multiple sites do not completely explain the pattern because samples from 1999 and 2000 were not highly variable, despite having been sampled from multiple sites. For whatever reason, populations in more established communities appear to contribute larvae more consistently to the plankton than those in recently disturbed ones. This variation in species composition caused the 2006 samples to cluster into 2 separate groups, independent of their sample date (Fig. 2). One possible explanation is that the southern (Ty/Io) sites are more susceptible to vagaries of currents because they have fewer neighboring populations than sites to the north (Adams \& Mullineaux 2008). Similarly, the abrupt nature of the decrease in larval diversity over a period of 1 mo between November and December 2006 remains a puzzle. This pattern was quite distinct, despite the variation in species abundance within each sampling period. A possible explanation for this is that the environmental events (earthquakes, changes in hydrology) that may have triggered a pulse of post-eruption spawning were long gone, and the early cohort of post-eruption larvae was no longer in the plankton.

\section{Natural versus anthropogenic disturbance}

In general, major disturbances not only cause massive mortality, but also alter the immediate post-disaster environment. These changes often favor opportunistic species, which can exploit the altered habitat during the recovery period (e.g. Capitella spp. polychaetes following oil spills (Grassle \& Grassle 1974)). Eruptions are, for vent species, routine disasters, which may occur at a frequency approaching that of an individual lifespan and result in an altered post-disaster habitat, generally with higher temperature, higher H2S, extensive bacterial mats and large areas of unoccupied hard substrate. A few vent species seem to thrive in these conditions and it is possible that they need the episodic availability of this environment to maintain their populations. However, the species that were adapted to the pre-eruption conditions probably cannot begin to rebuild their populations until the temperatures and H2S concentrations drop to acceptable levels, and recovery of the full suite of pre-eruption species may take 5 to 10 yr or even longer (Marcus et al. 2009). The situation is in some respects similar to fire-adapted 
ecosystems, in which periodic burns appear to be necessary for some species to reproduce (Christensen 1985), or to coral reefs, where hurricane disturbance may prevent dominance of rapidly growing staghorn corals (Connell \& Keough 1985). In both these cases, disturbance is necessary to maintain species diversity as a whole by creating a balance between the opportunists and the later, slower-growing colonists.

It is uncertain, however, whether the adaptations that allow vent species to recolonize after eruptions would be effective after a different type of disturbance such as seafloor mining. Like an eruption, a mining operation would clearly cause massive mortality and some disruptions to the local venting activity (Levin et al. 2009, Ramirez-Llodra et al. 2011), but the rubble- and sediment-covered substrate left afterward would be quite different from the natural habitat. Larvae of some vent species (e.g. grazing limpets or barnacles) may not settle without hard substratum, while others may find the rubble chemically unsuitable. If early settlers facilitate later arrivals, as has been shown for Tevnia jerichonana and Riftia pachyptila (Mullineaux et al. 2000), their absence could precipitate a cascade of changes in the developing community which may persist until another eruption swept the slate clean again. The estimate of a decade for recovery of vent communities from mining (Van Dover 2011) is based on observed successional processes after natural eruptions on the EPR and Juan de Fuca ridges, where suitable substratum was available directly after the disturbance. Given these uncertainties, it is difficult to predict whether and how vent communities will recover after mining, which is expected to begin at the Solwara 1 vent in the territorial waters of Papua New Guinea in the near future (Nautilus Minerals 2011, Duffy 2012).

A final concern is what the effect would be of both forms of disturbance acting in sequence on a community that may not have reached a steady state after the first. Paine et al. (1998, p. 536) state, 'rapidly compounded perturbations have more serious implications for longterm alterations of community state, occasionally or even often generating a different assemblage of species', and go on to give several examples. Different forms of disturbance will affect individual species in different ways; to use the coral reef example, a hurricane will damage the reef species differently than a bleaching event or the invasion of a predator like the crown-ofthorns. Species that are relatively resistant to one type of disturbance may be more vulnerable to another, and both forms acting together are likely to produce more severe and persistent damage than either one alone. Predictions of vent community resilience to mining need to take into 
account the additive, or potentially even nonlinear, effects of combined natural and human disturbance.

\section{Acknowledgements.}

We thank the captains and crew of RV 'Atlantis', the pilots and technicians of DSV 'Alvin' and the principal investigators (M. Lilley, A. Thurnherr and J. Ledwell) and science parties of AT 11-20, AT 15-12, AT 15-14 and AT 15-26 for their assistance at sea. Support was provided by National Science Foundation Grant OCE-0424953 and a Woods Hole Oceanographic Institution grant from the Deep Ocean Exploration Institute.

\section{LITERATURE CITED}

Adams DK, Mullineaux LS (2008) Supply of gastropod larvae to hydrothermal vents reflects transport from local larval sources. Limnol Oceanogr 53:1945-1955

Beaulieu SE, Mullineaux LS, Adams DK, Mills SW (2009) Comparison of a sediment trap and plankton pump for time-series sampling of larvae near deep-sea hydrothermal vents. Limnol Oceanogr Methods 7:235-248

Connell JH, Keough MJ (1985) Disturbance and patch dynamics of subtidal marine animals on hard substrata. In: Pickett STA, White PS (eds) The ecology of natural disturbance and patch dynamics. Academic Press, Orlando, FL, p 125-152

Dreyer JC, Knick KE, Flickinger WB, Van Dover CL (2005) Development of macrofaunal community structure in mussel beds on the northern East Pacific Rise. Mar Ecol Prog Ser 302:121-134

Duffy A (2012) PNG approves world’s first deep sea mining project. Australian Mining. https://www.miningaustralia.com.au/news/png-approves-world-s-first-deep-sea-miningproject, accessed 15 August 2012

Dziak RP, Bohnenstiehl DR, Matsumoto H, Fowler MJ, Haxel JH, Tolstoy M, Waldhauser F (2009) January 2006 seafloor-spreading event at 950'N, East Pacific Rise: ridge dike intrusion and transform fault interactions from regional hydroacoustic data. Geochem Geophys Geosyst 10:Q06T06, doi:10.1029/2009GC002388 
Fornari DJ, Von Damm KL, Bryce JG, Cowen JP, Ferrini V, Fundis A, Lilley MD, Luther GW, Mullineaux LS, Perfit MR, Meana-Prado MF, Rubin KH, Seyfried WE, Shank TM, Soule SA, Tolstoy M, White SM (2012) The East Pacific Rise between $9^{\circ} \mathrm{N}$ and $10^{\circ} \mathrm{N}$ : twenty-five years of integrated, multidisciplinary oceanic spreading center studies. Oceanography 25:1843

Govenar B, Le Bris N, Gollner S, Glanville J, Aperghis AB, Hourdez S, Fisher CR (2005) Epifaunal community structure associated with Riftia pachyptila aggregations in chemically different hydrothermal vent habitats. Mar Ecol Prog Ser 305:67-77

Grassle JF, Grassle JP (1974) Opportunistic life histories and genetic systems in marine benthic polychaetes. J Mar Res 32:253-284

Hoagland P, Beaulieu S, Tivey MA, Eggert RG, German C, Glowka L, Lin J (2010) Deep-sea mining of seafloor massive sulfides. Mar Policy 34:728-732

Johnson SB, Waren A, Vrijenhoek RC (2008) DNA barcoding of Lepetodrilus limpets reveals cryptic species. J Shellfish Res 27:43-51

Le Bris N, Govenar B, Le Gall C, Fisher CR (2006a) Variability of physico-chemical conditions in $9^{\circ} 50^{\prime} \mathrm{N}$ EPR diffuse flow vent habitats. Mar Chem 98:167-182

Le Bris N, Rodier P, Sarradin PM, Le Gall C (2006b) Is temperature a good proxy for sulfide in hydrothermal vent habitats? Cah Biol Mar 47:465-470

Levin LA, Mendoza GF, Konotchick T, Lee R (2009) Macrobenthos community structure and trophic relationships within active and inactive Pacific hydrothermal sediments. Deep-Sea Res II 56:1632-1648

Lutz RA, Jablonski D, Turner RD (1984) Larval development and dispersal at deep-sea hydrothermal vents. Science 226:1451-1454

Lutz RA, Shank TM, Luther GW, Vetriani C, Tolstoy M, Nuzzio DB, Moore TS, Waldhauser F, Crespo-Medina M, Chatziefthimiou AD, Annis ER, Reed AJ (2008) Interrelationships between vent fluid chemistry, temperature, seismic activity, and biological community structure at a mussel-dominated, deep-sea hydrothermal vent along the East Pacific Rise. J Shellfish Res 27:177-190 
Marcus J, Tunnicliffe V, Butterfield DA (2009) Post-eruption succession of macrofaunal communities at diffuse flow hydrothermal vents on Axial Volcano, Juan de Fuca Ridge, Northeast Pacific. Deep-Sea Res II 56:1586-1598

McCook LJ (1994) Understanding ecological community succession: causal models and theories, a review. Vegetatio 110:115-147

McGillicuddy DJ, Lavelle W, Thurnherr AM, Kosnyrev VK, Mullineaux LS (2010) Larval dispersion along an axially symmetric mid-ocean ridge. Deep-Sea Res I 57:880-892

Metaxas A (2011) Spatial patterns of larval abundance at hydrothermal vents on seamounts: evidence for recruitment limitation. Mar Ecol Prog Ser 437:103-117

Micheli F, Peterson CH, Mullineaux LS, Fisher CR, Mills SW, Sancho G, Johnson GA, Lenihan HS (2002) Predation structures communities at deep-sea hydrothermal vents. Ecol Monogr 72:365-382

Mills SW, Beaulieu SE, Mullineaux LS (2009) Photographic identification guide to larvae at hydrothermal vents. Tech Rep WHOI-2009-05, Woods Hole Oceanographic Institution, Woods Hole, MA

Moore TS, Shank TM, Nuzzio DB, Luther GW (2009) Time-series chemical and temperature habitat characterization of diffuse flow hydrothermal sites at 950'N East Pacific Rise. DeepSea Res II 56:1616-1621

Mullineaux LS, Fisher CR, Peterson CH, Schaeffer SW (2000) Vestimentiferan tubeworm succession at hydrothermal vents: use of biogenic cues to reduce habitat selection error? Oecologia 123:275-284

Mullineaux LS, Peterson CH, Micheli F, Mills SW (2003) Successional mechanism varies along a gradient in hydrothermal fluid flux at deep-sea vents. Ecol Monogr 73:523-542

Mullineaux LS, Mills SW, Sweetman AK, Beaudreau AH, Metaxas A, Hunt HL (2005) Vertical, lateral and temporal structure in larval distributions at hydrothermal vents. Mar Ecol Prog Ser 293:1-16

Mullineaux LS, Adams DK, Mills SW, Beaulieu SE (2010) Larvae from afar colonize deep-sea hydrothermal vents after a catastrophic eruption. Proc Natl Acad Sci USA 107:7829-7834 
Mullineaux LS, Le Bris N, Mills SW, Henri P, Bayer SR, Secrist RG, Siu N (2012) Detecting the influence of initial pioneers on succession at deep-sea vents. PLoS ONE 7:e50015

Nautilus Minerals (2011) Nautilus granted mining lease. Nautilus Minerals. www.nautilusminerals.com/s/Media-NewsReleases.asp?ReportID=437932\&_Type=NewsReleases\&_Title=Nautilus-Granted-Mining-Lease (accessed 15 August 2012)

Neubert M, Mullineaux LS, Hill MF (2006) A metapopulation approach to interpreting diversity at deep-sea hydrothermal vents. In: Kritzer J, Sale P (eds) Marine metapopulations. Elsevier Academic Press, Burlington, MA, p 321-350

Paine RT, Tegner MJ, Johnson EA (1998) Compounded perturbations yield ecological surprises. Ecosystems 1:535-545

Pielou EC (1969) Introduction to mathematical ecology. Wiley-Interscience, New York, NY

Ramirez-Llodra E, Tyler PA, Baker MC, Bergstad OA, Clark MR, Escobar E, Levin LA, Menot L, Rowden AA, Smith CR, Van Dover CL (2011) Man and the last great wilderness: human impact on the deep sea. PLoS ONE 6:e22588

Shank TM, Fornari DJ, Von Damm KL, Lilley MD, Haymon RM, Lutz RA (1998) Temporal and spatial patterns of biological community development at nascent deep-sea hydrothermal vents (950'N, East Pacific Rise). Deep-Sea Res II 45:465-515

Shanks AL (1998) Apparent oceanographic triggers to the spawning of the limpet Lottia digitalis (Rathke). J Exp Mar Biol Ecol 222:31-41

Soule SA, Fornari DJ, Perfit MR, Rubin KH (2007) New insights into mid-ocean ridge volcanic processes from the 2005-06 eruption of the East Pacific Rise, 946'-56'N. Geology 35:1079_ 1082

Sousa WP (2001) Natural disturbance and the dynamics of marine benthic communities. In: Bertness MD, Gaines SD, Hay ME (eds) Marine community ecology. Sinauer, Sunderland, MA, p 85-130

Thurnherr AM, Ledwell JR, Lavelle JW, Mullineaux LS (2011) Hydrography and circulation near the crest of the East Pacific Rise between $9^{\circ}$ and $10^{\circ}$ N. Deep-Sea Res I 58:365-376 
Tolstoy M, Cowen JP, Baker ET, Fornari DJ, Rubin KH, Shank TM, Waldhauser F, Bohnenstiehl DR, Forsyth DW, Holmes RC, Love B, Perfit MR, Weekly RT, Soule SA, Glazer B (2006) A sea-floor spreading event captured by seismometers. Science 314:19201922

Tunnicliffe V (1997) Biological colonization of new hydrothermal vents following an eruption on Juan de Fuca Ridge. Deep-Sea Res I 44:1627-1644

Tyler PA, Young CM (1999) Reproduction and dispersal at vents and cold seeps. J Mar Biol Assoc UK 79:193-208

Van Dover CL (2003) Variation in community structure within hydrothermal vent mussel beds of the East Pacific Rise. Mar Ecol Prog Ser 253:55-66

Van Dover CL (2011) Mining seafloor massive sulphides and biodiversity: What is at risk? ICES J Mar Sci 68:341-348

Van Dover CL, Lutz RA (2004) Experimental ecology at deep-sea hydrothermal vents: a perspective. J Exp Mar Biol Ecol 300:273-307

Van Dover C, Smith CR, Ardron J, Arnaud S, Beaudoin, Y, Bezaury, J, Boland, G, Billet, D, Carr, M, Cherkashov, G, Cook, A, DeLeo, F, Dunn, D, Fisher, CR, Godet, L, Gjerde, K, Halpin, P, Levin, L, Lodge, M, Menot, L, Miller, K, Milton, D, Naudts, L, Nugent, C, Pendleton, L, Plouviez, S, Rowden, A, Santos, R, Shank, T, Smith, S, Tao, C, Tawake, A, Thurnherr, A, Treude, T (2011) Environmental management of deep-sea chemosynthetic ecosystems: justification of and considerations for a spatially-based approach. ISA Tech Study 9, International Seabed Authority, Kingston

Von Damm K, Parker C, Beers K (2004) Update on the hydrothermal and biological status of the EPR ISS ‘Bull’s-Eye’ at 950'N. Ridge 2000 Events 2:25-26 


\section{Figure Captions}

Fig. 1. Study area near $9^{\circ} 50^{\prime} \mathrm{N}$ on the East Pacific Rise, showing the areas affected by the 2006 eruption (outlined in blue) and the pump sampling sites in November 2004 (blue dot), November 2006 (red dots), December 2006 (gold dots), and November 2007 (green dot). Large dots indicate multiple samples at a single site

Fig. 2. Bray-Curtis cluster analysis (single link) of similarities in species abundance between pump samples. Pre-eruption samples were all from East Wall (November 2004); post-eruption samples were from Riftia Field, Tica and Ty/Io (Cruise L1 = November 2006; Cruise L2 = December 2006; Cruise L3 = November 2007)

Fig. 3. Nonmetric multi-dimensional scaling (nMDS) analysis of abundance of selected gastropod species and morphotypes in samples. Analysis conducted on Pearson correlation matrix. Kruskal stress $=0.076$; proportion of variance $=0.976$

Fig. 4. Abundance (number per $40000 \mathrm{l}$ ) of the 4 most common gastropod species or morphotypes in the pre-eruption group (left) and post-eruption group (right) on cruises in November 2004, November 2006 (2006-1), December 2006 (2006-2), and November 2007. Letters indicate significant differences (post-hoc Tukey tests for pairwise comparisons). Error bars are standard error

Fig. 5. Rarefaction curves for samples from November 2004, November 2006 (2006-1), December 2006 (2006-2) and November 2007, pooled by cruise (thick lines) and individually (thin lines).

Fig. 6. Abundance of vent larvae pooled (solid circles), and sub-groups of vent gastropod larvae (diamonds) and vent polychaete larvae (triangles) from 4 cruises in this study (2004, 2006-1, 2006-2 and 2007) and 2 cruises from previous expeditions (1999 and 2000; Mullineaux et al. 2005). Means and standard error are displayed for vent larvae; letters above symbols denote significant difference as detected by ANOVA and post-hoc Tukey test (for vent larvae pooled, log-transformed, $\mathrm{p}=0.015, \mathrm{~F}=4.03, \mathrm{df}=5$ ). ANOVA of gastropod abundance (log transformed) shows no significant differences between sample dates ( $\mathrm{p}=0.23, \mathrm{~F}=1.55, \mathrm{df}=5)$; ANOVA of polychaete abundance (log-transformed) shows 2004 as greater than all other sample dates $(\mathrm{p}<0.001, \mathrm{~F}=9.16, \mathrm{df}=5)$ 
Table 1. Mean number of individuals per $40000 \mathrm{l}$ filtered classified to species groups or morphotypes, from 4 cruises, 2004 to 2007. Standard deviations are in parentheses; $n=5$ (2004), $\mathrm{n}=3$ (2006-1), $\mathrm{n}=3$ (2006-2) and $\mathrm{n}=4$ (2007)

\begin{tabular}{|c|c|c|c|c|}
\hline Cruise & 2004 & $2006-1$ & $2006-2$ & 2007 \\
\hline \multicolumn{5}{|l|}{ GASTROPODA } \\
\hline Unknown A & $14.0(9.6)$ & 4.7 (2.9) & $3.0(2.6)$ & $1.3(1.9)$ \\
\hline Clypeosectus delectus & $5.0(3.7)$ & $1.3(1.2)$ & $0.3(0.6)$ & 0 \\
\hline Ctenopelta porifera & $0.2(0.4)$ & $3.7(3.1)$ & $0.7(1.2)$ & $0.5(0.6)$ \\
\hline Cyathermia naticoides & $28.2(18.6)$ & $4.0(3.0)$ & $3.0(3.6)$ & $3.3(2.8)$ \\
\hline Echinopelta fistulosa & 0 & $2.3(3.2)$ & $0.3(0.6)$ & $0.5(0.6)$ \\
\hline Eulepetopsis vitrea & $3.0(1.6)$ & $0.7(0.6)$ & 0 & 0 \\
\hline Gorgoleptis & $5.0(2.1)$ & $55.0(29.9)$ & $53.3(57.4)$ & $13.8(9.0)$ \\
\hline \multicolumn{5}{|l|}{ emarginatus } \\
\hline Gorgoleptis spiralis & $3.4(1.1)$ & $5.7(3.8)$ & $2.0(1.0)$ & $1.5(1.3)$ \\
\hline Laeviphitus sp. & $13.6(5.9)$ & $10.3(9.2)$ & $1.0(1.0)$ & $2.5(1.3)$ \\
\hline Lepetodrilus spp. & $87.0(31.9)$ & $213.7(134.0)$ & $177.0(162.6)$ & $162.8(87.5)$ \\
\hline Lepetodrilus $190 \mu \mathrm{m}$ & $0.8(1.1)$ & $0.3(0.6)$ & 0 & $0.5(0.6)$ \\
\hline Lirapex granularis & $0.6(0.9)$ & $1.3(1.2)$ & $0.7(1.2)$ & $1.3(1.9)$ \\
\hline Melanodrymia & $2.5(2.4)$ & $2.3(0.6)$ & 0 & 0 \\
\hline \multicolumn{5}{|l|}{ aurantiaca } \\
\hline Neomphalus fretterae & $2.6(1.5)$ & $2.0(1.7)$ & $0.3(0.6)$ & $0.3(0.5)$ \\
\hline Pachydermia laevis & $3.2(1.6)$ & $2.0(1.7)$ & 0 & $1.3(1.3)$ \\
\hline Peltospira sp. & $13.2(8.3)$ & $5.0(1.0)$ & $0.7(1.2)$ & $5.0(5.0)$ \\
\hline Unknown W & $1.8(1.3)$ & $1.0(1.7)$ & $0.3(0.6)$ & $0.8(1.5)$ \\
\hline Rhynchopelta & $2.8(1.5)$ & $2.0(1.0)$ & $0.7(1.2)$ & 0 \\
\hline \multicolumn{5}{|l|}{ concentrica } \\
\hline Sutilizona theca & $2.8(2.4)$ & $7.0(7.8)$ & $6.0(5.3)$ & $3.0(1.4)$ \\
\hline Unknown 5 & $13.8(9.4)$ & $14.3(11.7)$ & $8.7(8.1)$ & $5.8(2.2)$ \\
\hline Unknown peltospirid & $3.0(1.6)$ & 0 & 0 & 0 \\
\hline \multicolumn{5}{|l|}{$210 \mu \mathrm{m}$} \\
\hline Unknown peltospirid & $3.2(1.3)$ & $3.3(3.2)$ & $1.0(1.0)$ & $0.5(0.6)$ \\
\hline \multicolumn{5}{|l|}{$240 \mu \mathrm{m}$} \\
\hline Rare gastropods $^{\mathrm{a}}$ & $2.8(1.5)$ & $2.3(2.1)$ & $0.3(0.6)$ & $1.0(0.8)$ \\
\hline
\end{tabular}




\section{BIVALVIA}

Bathymodiolus

$0.2(0.4)$

0

$0.3(0.6)$

$0.3(0.5)$

thermophilus

POLYCHAETA

Ophryotrocha akessoni

$\begin{array}{cccc}145.8(63.3) & 17.0(5.2) & 33.3(50.0) & 5.5(1.0) \\ 3.0(1.6) & 1.7(1.5) & 0 & 0.3(0.5) \\ 5.6(6.7) & 4.3(4.9) & 1.3(1.2) & 1.5(1.7) \\ 2.4(3.2) & 0.7(0.6) & 0 & 1.0(1.4) \\ 106.4(49.4) & 12.3(5.9) & 31.0(45.1) & 16.3(7.2) \\ 14.6(7.1) & 3.3(3.1) & 3.3(3.5) & 2.0(0.8) \\ 13.6(7.3) & 3.3(2.9) & 0 & 0.8(1.0) \\ 0.2(0.4) & 3.0(2.6) & 5.7(9.0) & 0.5(0.6) \\ 68.0(57.8) & 12.7(9.9) & 17.0(21.7) & 8.3(4.6) \\ 1.2(1.1) & 0.3(0.6) & 0.7(0.6) & 0.5(1.0)\end{array}$

Nereis sp.

Spionidae

Glyceridae

Chaetosphaerid

Polynoid

Archinome rosacea

Hesionidae

Nectochaete $^{\mathrm{b}}$

Trochophore larvae $^{\mathrm{b}}$

ARTHROPODA

Amphipoda

68.0 (38.3)

62.7 (24.5)

19.3 (11.9)

118.0 (33.1)

Isopoda

$1.6(1.5)$

0

Cyprid larvae ${ }^{\mathrm{b}}$

$0.6(0.5)$

3.3 (5.8)

$3.0(0.6)$

$0.8(1.0)$

Bythograea thermydron

$0.2(0.4)$

$0.3(0.6)$

0

0.5 (1.0)

Shrimp juvenile

$2.3(1.2)$

0

$0.5(1.0$

Leptostraca

$1.7(0.6)$

$0.3(0.6)$

$0.3(0.5)$

$0.2(0.4)$

$1.7(2.1)$

48.5 (58.4)

MISCELLANEOUS

GROUPS

$\begin{array}{lcccc}\text { Platyhelminthes }^{\mathrm{b}} & 0.6(0.9) & 4.0(4.0) & 0 & 0.5(1.0) \\ \text { Benthic foraminifera }^{\mathrm{b}} & 52.0(35.2) & 25(11.5) & 6.3(4.2) & 282.5(174.0) \\ \text { Cyphonautes larvae }^{\mathrm{b}} & 1.2(0.8) & 0 & 1.3(1.5) & 1.5(1.3) \\ \text { Tretomphalus-like }^{\text {Planulae }}{ }^{\mathrm{b}} & 0 & 0 & 0 & 3.0(3.0) \\ & 0 & 0 & 0.3(0.6) & 0.3(0.5)\end{array}$

${ }^{\mathrm{a}}$ Morphotypes with <5 individuals collected: Bathymargarites symplector, Melanodrymia galeronae, Melanodrymia-like sp. B, Phymorhynchus major, Unknown 8, Unknown U, Unknown 7175 m, Unknown 9, Pointy apex $150 \mu \mathrm{m}$, Unknown punctate $210 \mu \mathrm{m}$, Unknown Pachydermia-like 220 m, Unknown neomphalid $290 \mu \mathrm{m}$; morphologies described in Mills et al. (2009) 
${ }^{\mathrm{b}}$ May include non-vent species 
Table 2. Multivariate analysis of variance (MANOVA) and univariate ANOVA comparing vent larval abundance for common pre- and post-eruption species or morphotypes during each of 4 cruises: November 2004 ( $\mathrm{n}=5$ samples); November 2006 (Cruise L1, n = 3); December 2006 (L2, n = 3); November 2007 (L3, $\mathrm{n}=4$ ). Logarithmic transformations $\ln (x+1)$ were performed on data when necessary to obtain homogeneity of variances. Post-hoc Tukey tests are shown in Fig. 4 for significant differences in species abundance between cruises. Bold indicates significance at $\mathrm{p}<0.05$

\begin{tabular}{lcccr}
\hline Source & $\mathrm{df}$ & Wilks $\lambda$ & $F$ & \multicolumn{1}{c}{$\mathrm{p}$} \\
\hline Pre-eruption species & 12,21 & $\mathbf{0 . 0 7}$ & 3.00 & $\mathbf{0 . 0 1}$ \\
Cyathermia naticoides & 3 & & 7.13 & $<\mathbf{0 . 0 1}$ \\
Neomphalus fretterae & 3 & & 4.90 & $\mathbf{0 . 0 2}$ \\
Peltospira sp. & 3 & & 8.29 & $<\mathbf{0 . 0 1}$ \\
Rhynchopelta concentrica & 3 & & 9.98 & $<\mathbf{0 . 0 1}$ \\
Post-eruption species & 12,21 & $\mathbf{0 . 0 6}$ & 3.31 & $<\mathbf{0 . 0 1}$ \\
Ctenopelta porifera & 3 & & 4.41 & $\mathbf{0 . 0 3}$ \\
Gorgoleptis emarginatus & 3 & & 8.59 & $<\mathbf{0 . 0 1}$ \\
Lepetodrilus spp. & 3 & & 0.80 & 0.52 \\
Sutilizona theca & 3 & & 0.64 & 0.61 \\
\hline
\end{tabular}


Figure 1
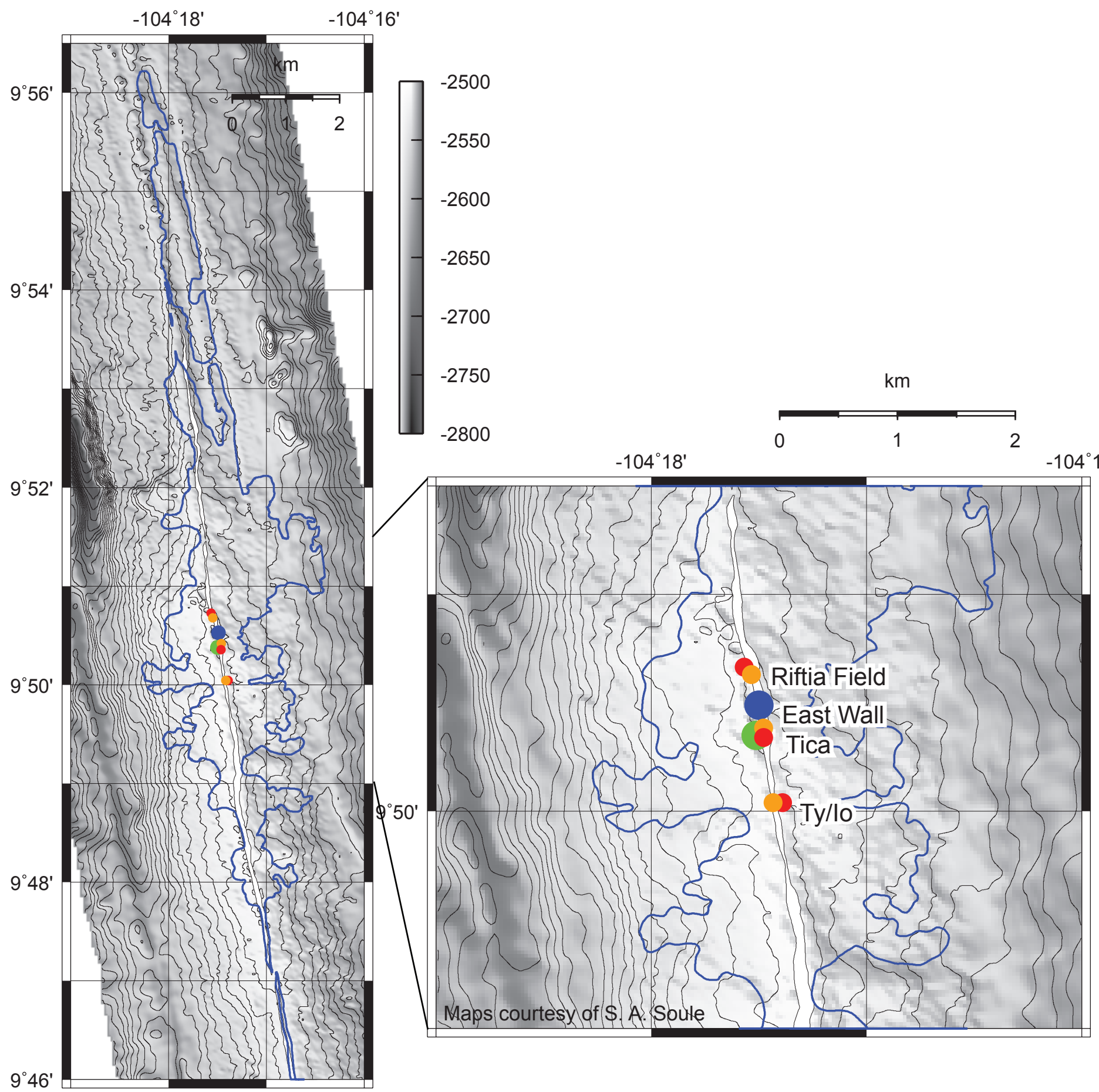
Figure 2

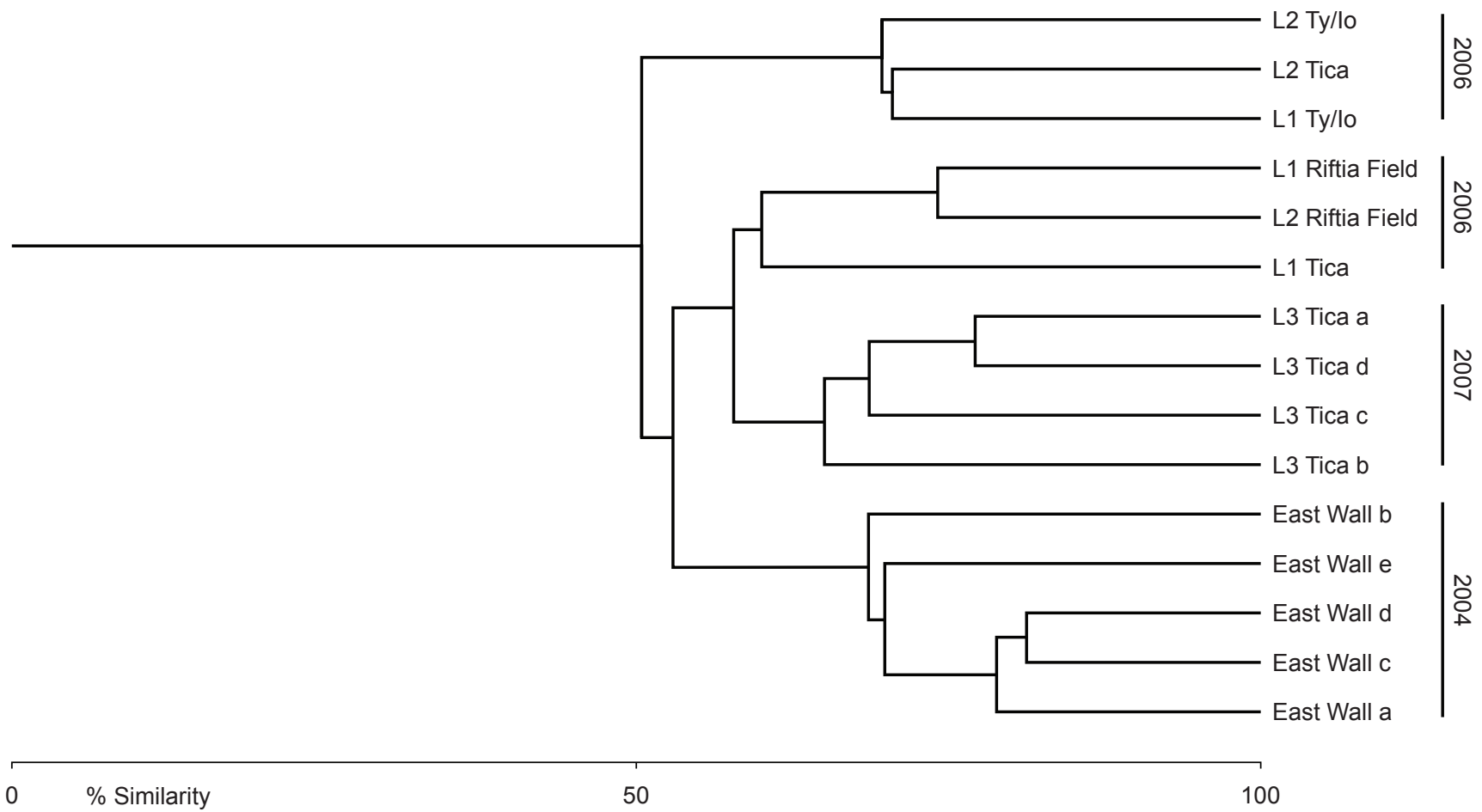


Figure 3

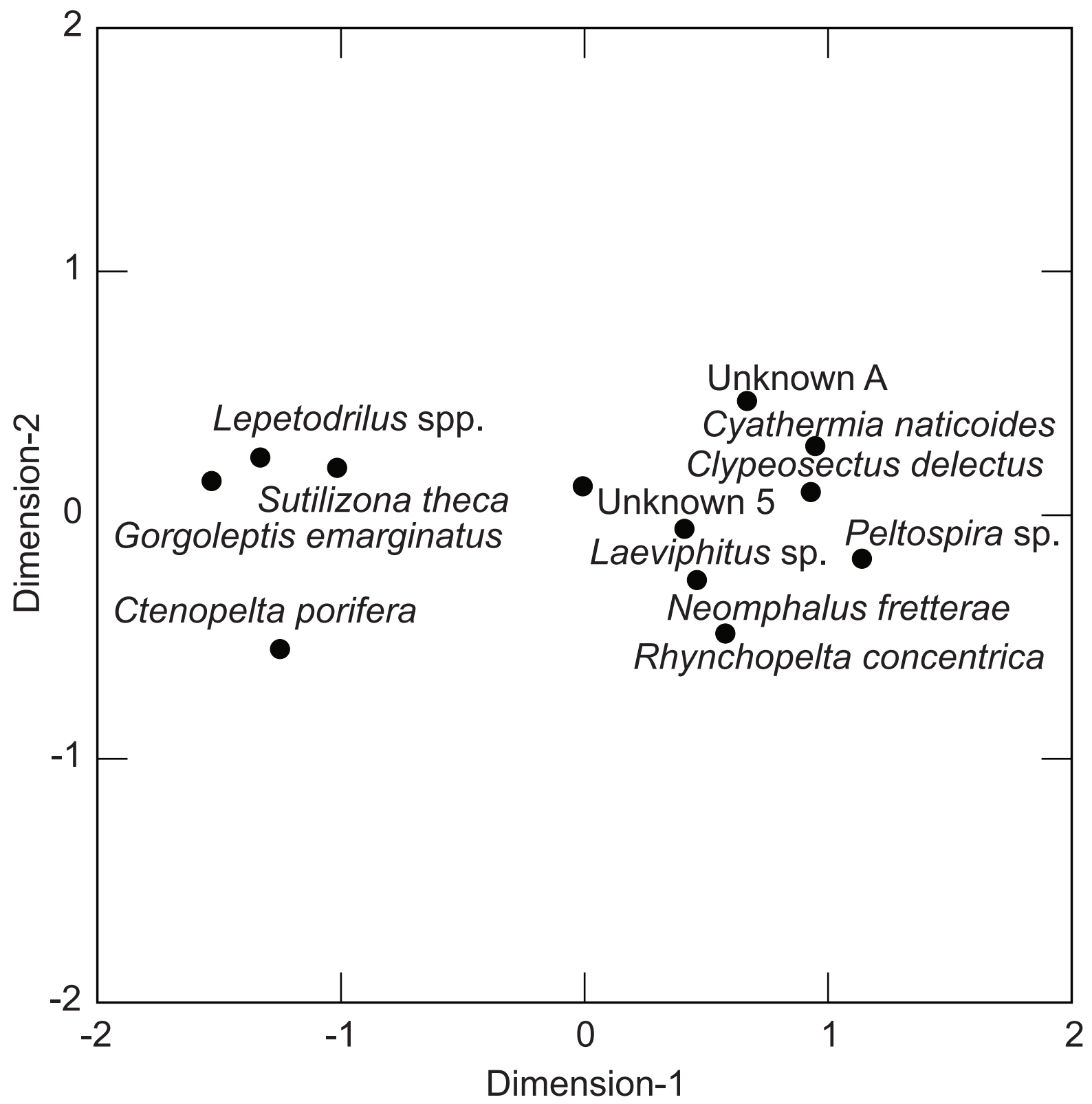


Figure 4
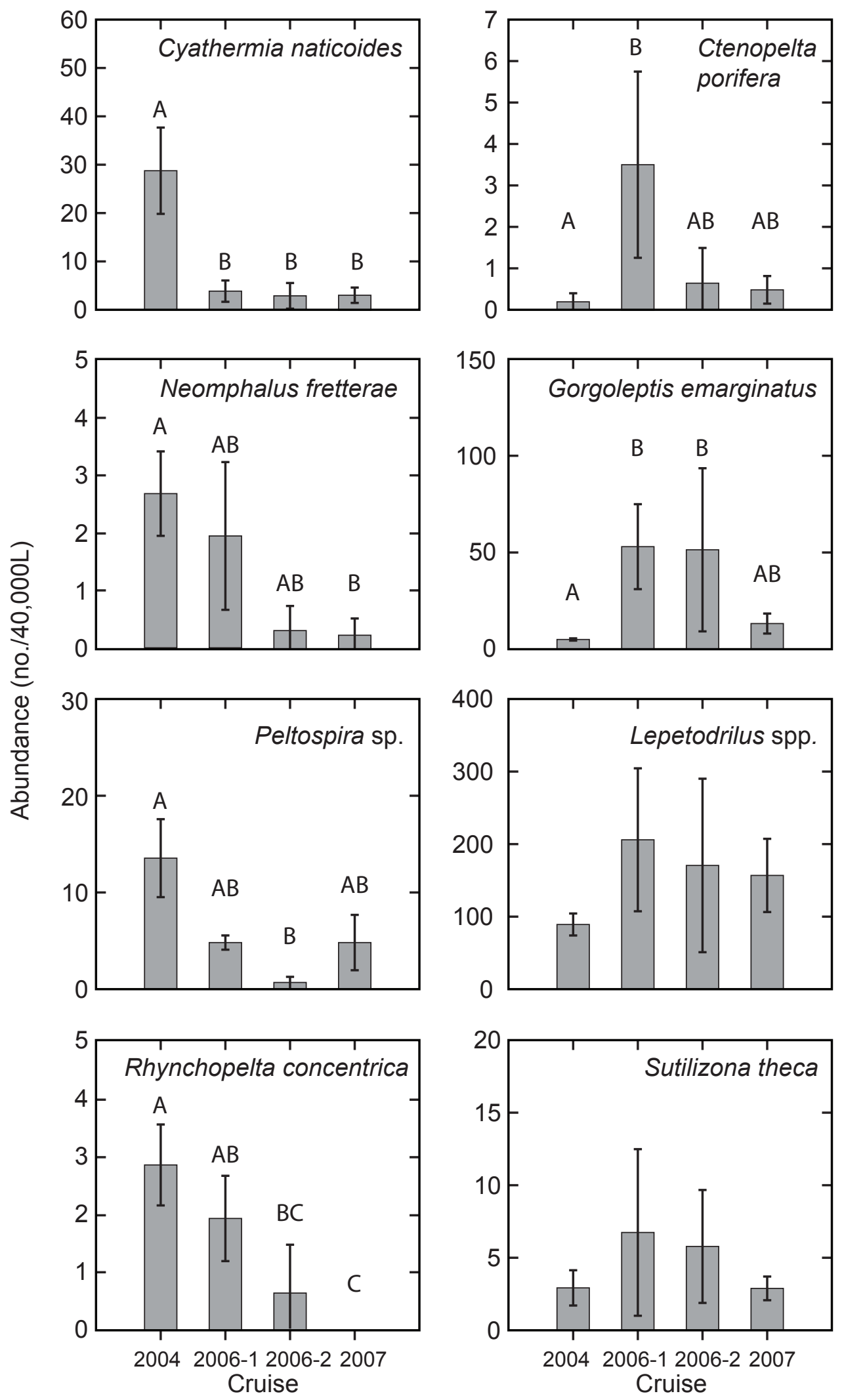
Figure 5

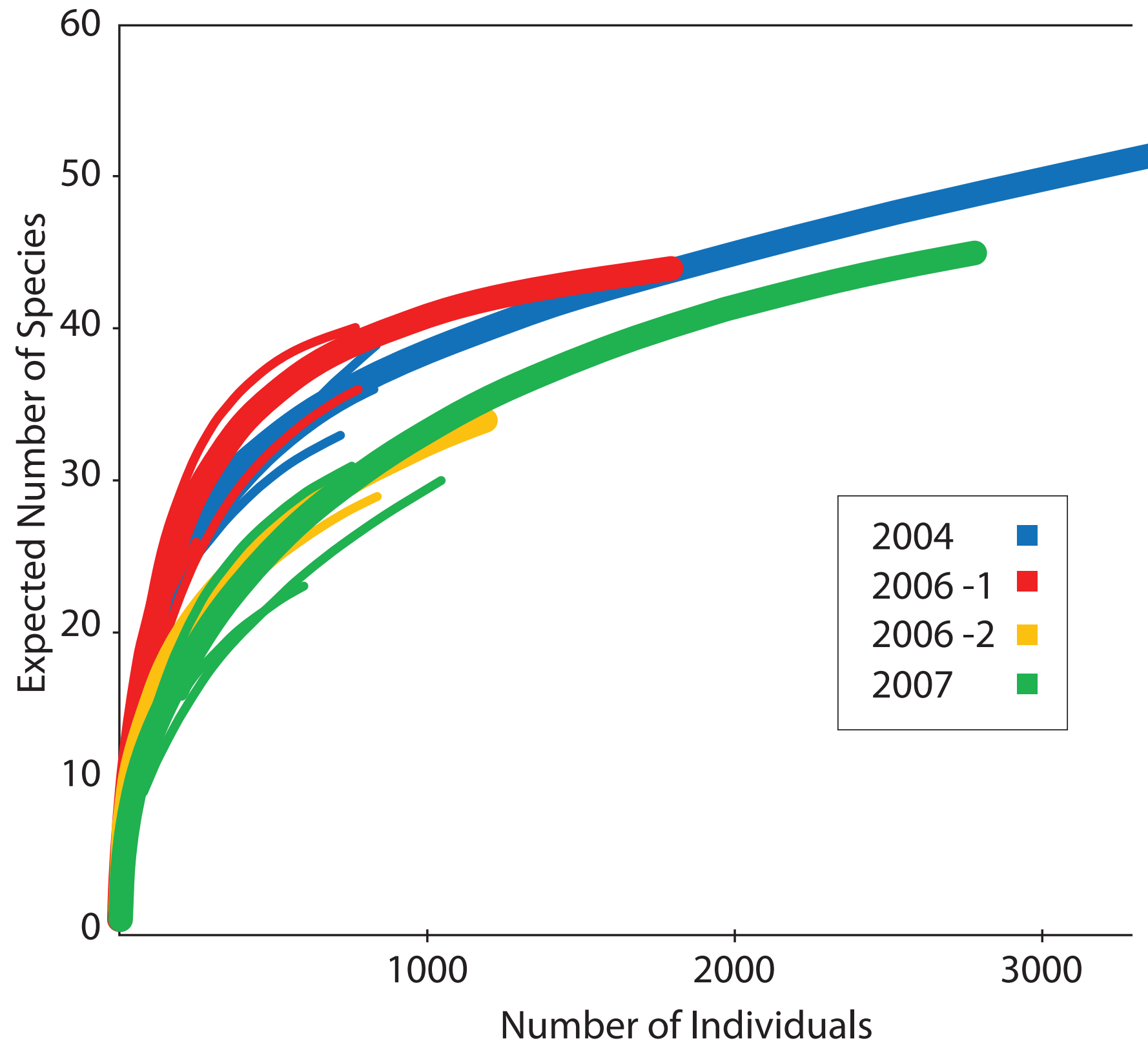


Figure 6

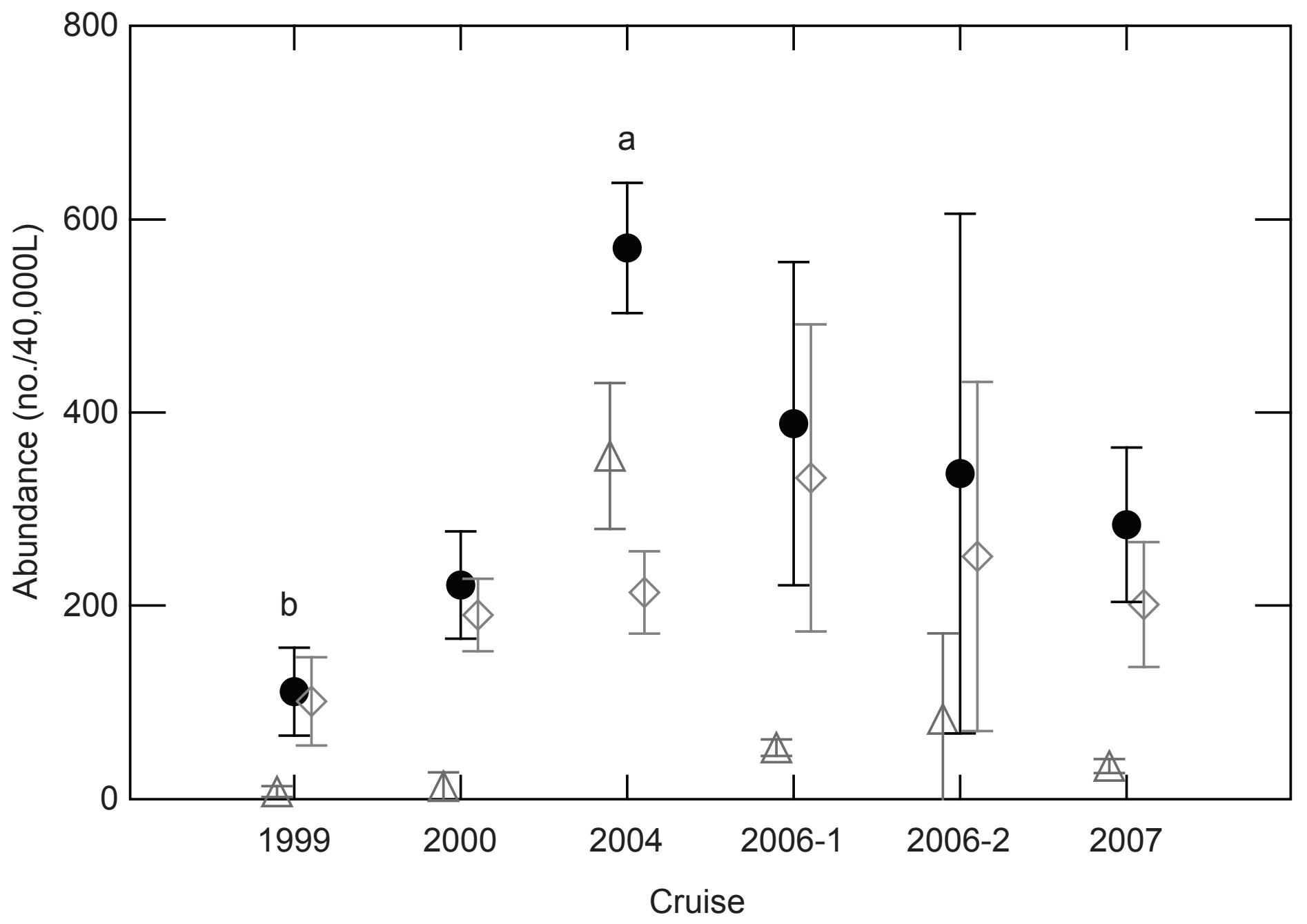

